\title{
ANALISIS FAKTOR-FAKTOR YANG MEMPENGARUHI KEPUTUSAN ISTRI PETANI MEMILIH BEKERJA ATAU TIDAK BEKERJA DI LUAR RUMAH TANGGA
}

\author{
Nyayu Neti Arianti ${ }^{1}$ \\ Basuki S. Priyono 1 \\ ${ }_{1}^{1}$ Staf Pengajar Jurusan Sosial Ekonomi Pertanian Fak.Pertanian UNIB
}

\begin{abstract}
The aims of this research were to know the reasons of farmer's wives behind their decision to work or not outside their family duties and to investigate the factors influenced their decision and how much their economic contribution to family income. This research took place in Peck Nearing village, Ponder Kelp sub regency, North Engulf regency. Descriptive and logic regression model was used to achieve the purposes. The research found that an economic reason that is the contributing to family income is the main reason for them to work which is indicating by $58,33 \%$ of 68 population, utilization of leisure time is decide reason for $80,56 \%$ population to while culture gender reason by $88,89 \%$. The logic model analysis showed that formal education, informal education, age, and family size influenced the farmer's wife decision, while the husband income as farmer did not, the economic contribution to family income was 56 , $94 \%$.
\end{abstract}

Key words: farmer's wife, decision making, off household

\section{PENDAHULUAN}

Kelangsungan rumah tangga sangat dipengaruhi oleh keadaan ekonomi keluarga, keadaan ekonomi merupakan hal yang sangat penting, karena dengan perekonomian keluarga yang baik maka semua kebutuhan hidup keluarga akan terpenuhi. Berbagai upaya ditempuh khususnya ibu rumah tangga dalam meningkatkan perekonomian rumah tangga dengan ikut berusaha. Menurut Pudjiwati dan Sajogyo (1996), di dalam keluarga atau rumah tangga dewasa ini, tidak asing lagi perempuan (istri) memiliki kedudukan atau peran ganda. Ini berarti di satu pihak sebagai ibu rumah tangga dalam keluarga, perempuan berperan sebagai tenaga kerja domestik, yang tidak mendatangkan hasil secara langsung. Namun demikian dalam kedudukan tersebut mereka memberikan dukungan bagi anggota keluarga yang lain sebagai pencari nafkah untuk memanfaatkan peluang kerja yang ada. Di lain pihak, sesuai dengan perkembangan masyarakat, perempuan juga berperan sebagai tenaga kerja di sektor publik informal sebagai pencari nafkah yang mendatangkan hasil secara langsung, seperti membuka warung, membantu suami di lahan pertanian, menjadi buruh pada suatu industri atau membuka peluang usaha sendiri seperti industri rumah tangga.

$42 \quad$ AGRISEP Vol. 4 No. 1, September 2005: 42 - 53 
Desa Pekik Nyaring merupakan salah satu kecamatan yang berada di kebupaten Bengkulu Utara. Desa Pekik Nyaring terdiri atas empat blok di mana dapat dikatakan hampir semua penduduk memiliki mata pencaharian pokok sebagai petani karena alokasi waktu mereka pertahun lebih banyak untuk melakukan pekerjaan pertanian. Suatu fenomena umum yang terjadi pada masyarakat agraris pedesaan di mana sebagian besar perempuan kelas bawah memanfaatkan waktu luangnya untuk menambah penghasilan keluarga ternyata terjadi di desa Pekik Nyaring. Berdasarkan fenomena di atas, maka dapat dirumuskan permasalahan yaitu (a) apa yang menjadi alasan perempuan memilih bekerja atau tidak bekerja di luar rumah tangga (b) faktor-faktor apa saja yang mempengaruhi perempuan memilih bekerja atau tidak bekerja di luar rumah tangga (c) berapa besar kontribusi pendapatan ibu rumah tangga yang bekerja terhadap pendapatan rumah tangga.

\section{METODE PENELITIAN}

Populasi dalam penelitian ini adalah istri petani yang bekerja dan tidak bekerja di desa Pekik Nyaring sebanyak 462 orang yang terbagi atas 4 blok, di mana blok I terdiri atas 129 orang, blok II 142 orang, blok III 102 orang dan blok IV terdri atas 89 orang (Sularno,2003). Responden yang diambil hanya sebagian dari populasi yaitu sebanyak 68 orang. Di mana pengambilan responden dilakukan secara Proportional Random Sampling (Nazir,1998). Menurut Singarimbun (1989) ada beberapa penelitian menyatakan besarnya sampel tidak boleh kurang dari 10\%. Lebih lanjut, dengan pertimbangan waktu, dana dan lokasi maka responden diambil sebanyak 15\% yang dianggap telah mewakili populasi yang ada. Perincian jumlah responden sebagai berikut:

Tabel 1. Jumlah Responden Penelitian

\begin{tabular}{cccc}
\hline No & Uraian & $\begin{array}{c}\text { Jumlah Populasi Istri Petani yang } \\
\text { Bekerja dan Tidak bekerja (org) }\end{array}$ & Jumlah Responden (org) \\
\hline 1 & Blok I & 129 & 19 \\
2 & Blok II & 142 & 21 \\
3 & Blok III & 102 & 15 \\
4 & Blok IV & 89 & 13 \\
\hline & Jumlah & 462 & 68 \\
\hline
\end{tabular}

Sumber : Selayang Pandang Desa Pekik Nyaring, 2000

Model analisis yang digunakan adalah model regresi logit. Seperti halnya regresi linier, regresi logit juga menggambarkan variabel tak bebas dengan varibel bebas. Bedanya variabel tak bebas dalam regresi logit bersifat biner yakni memiliki nilai yang diskontinue 1 atau 0.Fungsi ini selanjutnya diuji $F$ dan t statistik. Dengan nilai Pi maka nilai Li dapat ditaksir : 


$$
\begin{aligned}
& L i=\operatorname{Ln} \frac{P i}{(1-P i)}=\beta_{0}+\beta_{1} X_{1}+U i \\
& L=\beta_{0}+\beta_{1} X_{1}+\beta_{2} X_{2}+\beta_{3} X_{3}+\beta_{4} X_{4}+\beta_{5} X_{5}+U i
\end{aligned}
$$

Keterangan :

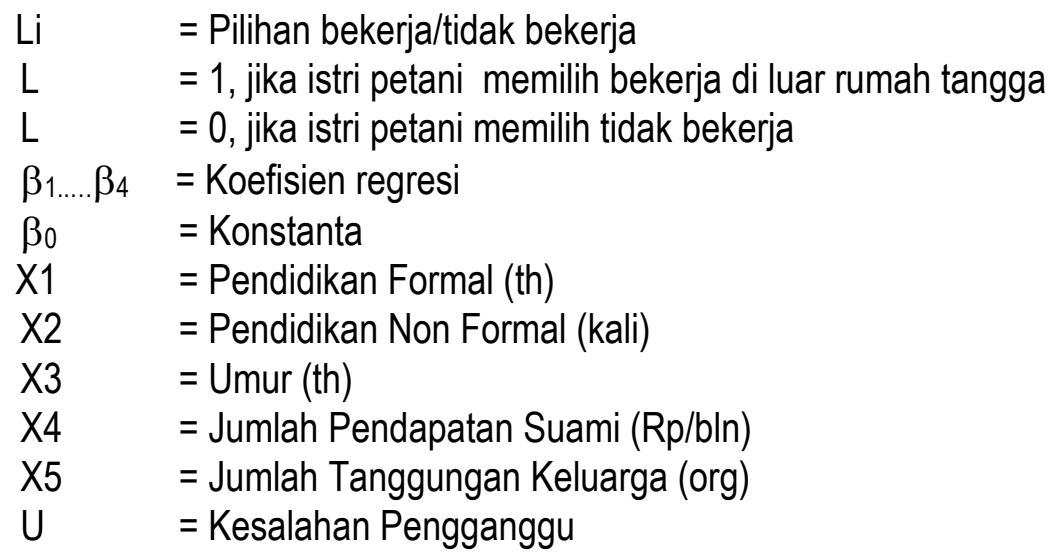

Kontribusi pendapatan istri petani yang bekerja terhadap pendapatan rumah tangga menurut Sumantri dan Ansori (2004) berpedoman pada pendapatan perempuan dari usahanya dibagi dengan pendapatan total rumah tangga dikalikan 100\%. Pendapatan tersebut dapat diklasifikasi menjadi sangat rendah $(1 \%-20 \%)$, rendah $(21 \%-4 \%)$, sedang/cukup $(41 \%$ $6 \%)$,tinggi $(61 \%-80 \%)$, sangat tinggi ( $\geq 81 \%)$

\section{HASIL DAN PEMBAHASAN}

\section{Alasan - Alasan Isteri Petani Untuk Bekerja atau Tidak Berkerja di Luar Rumah Tangga}

Pendapatan suami istri petani bersumber dari pertanian, supir, dan buruh. Hasil penelitian menunjukan bahwa jumlah pendapatan suami perempuan yang bekerja rata-rata Rp.573.305,56,- per bulan dengan kisaran Rp 100.0000- Rp 1.940 .000 dan pendapatan suami perempuan yang tidak bekerja rata-rata sebesar Rp.1.052.656,25,- per bulan dengan kisaran pendapatan 500.000-3.800.000. Dapat dilihat jelas perbedaan yang sangat mencolok antara pendapatan suami perempuan yang bekerja dengan perempuan yang tidak bekerja. Jumlah pendapatan suami perempuan bekerja hanya setengah dari jumlah pendapatan suami perempuan yang tidak bekerja. Kecilnya pendapatan suami menyebabkan perempuan memilih untuk bekerja, agar memperoleh pendapatan untuk membantu suami memenuhi kebutuhan 
keluarga. Sedang pendapatan suami yang relatif tinggi membuat perempuan lebih memilih tidak bekerja di luar rumah tangga karena telah merasa cukup dengan pendapatan suaminya.

Tabel 2 Jumlah Pendapatan Suami Istri petani yang Memilih Bekerja atau Tidak Bekerja di Luar Rumah Tangga

\begin{tabular}{ccccc}
\hline \multirow{2}{*}{$\begin{array}{c}\text { Pendapatan } \\
\text { (Rp/Bln) }\end{array}$} & \multicolumn{2}{c}{ Perempuan Bekerja } & \multicolumn{2}{c}{ Perempuan tidak Bekerja } \\
\cline { 2 - 5 } & $\begin{array}{c}\text { Jumlah } \\
\text { (orang) }\end{array}$ & $\begin{array}{c}\text { Persentase } \\
(\%)\end{array}$ & $\begin{array}{c}\text { Jumlah } \\
\text { (orang) }\end{array}$ & Persentase (\%) \\
\hline $100.000-840.000$ & 29 & 80,56 & 18 & 56,25 \\
$841.000-1.581 .000$ & 5 & 13,89 & 8 & 25,00 \\
$1.582 .000-2.322 .000$ & 2 & 5,55 & 3 & 9,38 \\
$2.323 .000-3.061 .000$ & 0 & 0 & 1 & 3,12 \\
$3.062 .000-3.800 .000$ & 0 & 0 & 2 & 6,25 \\
\hline Jumlah & 36 & 100,00 & 32 & 100,00 \\
\hline Rata-rata & \multicolumn{3}{c}{$573.305,56$} & \multicolumn{2}{c}{$500.000-3.800 .000$} \\
\hline Kisaran & \multicolumn{3}{c}{$100.000-1.940 .000$} &
\end{tabular}

Sumber : Data Primer, 2005

Jumlah pendapatan suami perempuan bekerja di luar rumah tangga dengan persentase tertinggi yaitu $80,56 \%$ pada jumlah pendapatan 100.000-840.000, persentase jumlah pendapatan suami perempuan yang bekerja lebih rendah dari pesentase perempuan yang tidak bekerja. Sedangkan pendapatan suami perempuan yang memilih tidak bekerja di luar rumah tangga mempunyai persentase $6,25 \%$ pada jumlah pendapatan tertinggi 3.062.000-3.800.000 dan pada jumlah pendapatan ini perempuan yang bekerja tidak ada atau 0\%. Dapat dilihat persentase jumlah pendapatan suami perempuan yang tidak bekerja lebih tinggi daripada persentase jumlah pendapatan suami perempuan yang bekerja. Hal ini membuat perempuan memilih tidak bekerja, karena merasa cukup dengan pendapatan yang diperoleh suaminya setiap bulan.

Hasil penelitian menunjukkan bahwa Ada tiga alasan yang ditanyakan kepada perempuan yang memilih bekerja di luar rumah tangga yaitu : alasan ekonomi, alasan sosial dan alasan budaya. Hasil penelitian mengenai alasan-alasan istri petani memilih bekerja di luar rumah tangga dapat di lihat pada Tabel 3. 
Tabel 3. Alasan-alasan Perempuan Memilih Bekerja di Luar Rumah Tangga

\begin{tabular}{|c|c|c|c|}
\hline No & Alasan-alasan & Jumlah (Jiwa) & Persentase (\%) \\
\hline 1. & $\begin{array}{l}\text { Alasan Ekonomi } \\
\text { a. Menambah penghasilan rumah tangga } \\
\text { (membantu suami) }\end{array}$ & 21 & 58,33 \\
\hline & b. Ingin mempunyai penghasilan sendiri & 11 & 30,56 \\
\hline & $\begin{array}{l}\text { c. Besarnya tanggungan keluarga } \\
\text { Alasan Sosial }\end{array}$ & 4 & 11,11 \\
\hline 2. & a. Mengisi waktu luang & 29 & 80,56 \\
\hline & $\begin{array}{l}\text { b. Menambah pergaulan atau keinginan } \\
\text { berteman }\end{array}$ & 3 & 8,33 \\
\hline & c. Ajakan teman/tetangga & 4 & 11,11 \\
\hline & $\begin{array}{l}\text { d. Meningkatkan prestise/gengsi } \\
\text { Alasan Budaya }\end{array}$ & 0 & 0 \\
\hline 3. & $\begin{array}{l}\text { a. Karena bekerja atau memperoleh } \\
\text { pendapatan untuk memenuhi kebutuhan } \\
\text { keluarga adalah tanggungjawab bersama } \\
\text { (suami-istri) }\end{array}$ & 32 & 88,89 \\
\hline & $\begin{array}{l}\text { b. Bekerja merupakan suatu kebiasaan bagi } \\
\text { perempuan yang telah menikah }\end{array}$ & 4 & 11,11 \\
\hline
\end{tabular}

Sumber : Data Primer, 2005

Alasan-alasan ekonomi adalah untuk menambah penghasilan rumah tangga, dimana perempuan memilih bekeja di luar rumah tangga untuk membantu suami dalam memenuhi kebutuhan keluarga. Perempuan yang memilih alasan ini berjumlah 21 orang atau 58,33 persen, dan untuk memperoleh pendapatan sendiri sebanyak 11 orang atau 30,56 persen karena dengan pendapatan sendiri mereka leluasa untuk menggunakan pendapatan yang diperoleh dari bekerja.

Alasan-alasan sosial adalah mengisi waktu luang sebanyak 29 orang dengan persentase sebesar 80,56 persen. Alasan istri petani memilih bekerja karena untuk mengisi waktu luang mempunyai persentase yang paling besar dari pada untuk menambah pergaulan /keinginan berteman dan ajakan teman atau tetangga, ini dapat di maklumi karena responden dapat memanfaatkan waktu dengan melakukan kegiatan positif, dan istri petani berpendapat dari pada mereka menganggur lebih baik mencari kesibukan dengan bekerja sehingga mereka dapat memenfaatkan waktu untuk memperoleh pendapatan.

Alasan budaya adalah untuk memperoleh pendapatan guna memenuhi kebutuhan keluarga adalah tanggung jawab bersama (suami-istri) sebanyak 32 orang atau sebesar 88,89 persen. Artinya, responden di Desa Pekik Nyaring berpendapat bahwa untuk memenuhi kebutuhan rumah tangga adalah tanggung jawab bersama (suami dan istri). Namun alasan 
perempuan memilih bekerja juga dikarenakan sudah menjadi budaya di Desa Pekik Nyaring bahwa perempuan yang telah menikah akan memilih untuk bekerja.

Berdasarkan hasil penelitian di lapangan maka didapat alasan-alasan responden memilih tidak bekerja di luar rumah tangga, ada tiga alasan yang ditanyakan kepada responden, yang pertama adalah alasan ekonomi yaitu perempuan memilih tidak bekerja karena merasa cukup dengan kondisi ekonomi sekarang. Perempuan yang memilih alasan ini berjumlah 10 orang $(31,25 \%)$. Hal ini dikarenakan istri merasa pendapatan suami yang diperoleh suidah cukup bahkan lebih untuk memenuhi kebutuhan keluarga dan mereka sudah puas dengan pendapatan suami yanga di terima setiap bulannya.

Alasan kedua adalah alasan sosial yaitu istri petani ini tidak mempunyai latar belakang pendidikan cukup. Ketidakmampuan baca tulis yang merupakan basis dalam menyerap informasi atau dikenal dengan buta huruf membuat kualitas SDM perempuan menjadi rendah. Mereka juga tidak punya keterampilan khusus sehingga mereka tidak mempunyai kesempatan untuk bekerja. Jumlah responden yang memilih alasan ini cukup besar, yaitu sebanyak 17 orang $(53,13 \%)$.

Alasan yang ketiga adalah alasan budaya yaitu tidak diizinkan suami dan ini merupakan salah satu budaya di desa Pekik Nyaring bahwa perempuan wajib mengikuti perintah suami, jika suami tidak mengizinkan istri petani untuk bekerja, maka mereka tidak bekerja. Pilihan untuk alasan ini berjumlah 5 orang $(15,62 \%)$, mereka berkeinginan untuk bekerja di luar rumah tangga tetapi suami mereka melarang untuk bekerja dengan alasan suami tidak ingin saat pulang dari bekerja tidak mendapatkan istri nya di rumah. Kemudian suaminya ingin perempuan lebih meluangkan waktu untuk keluarga, memberikan perhatian yang lebih dan bimbingan yang penuh untuk keluarganya, setiap hari mereka harus mempersiapkan semua kebutuhan baik suami dan anak-anak nya yang harus berangkat bekerja dan sekolah. Kewajiban-kewajiban inilah yang tidak memungkinkan untuk mereka tinggalkan. Alasan istri petani memilih tidak bekerja di luar rumah tangga dapat di lihat pada Tabel 4. 
Tabel 4. Alasan- alasan Istri petani Memilih Tidak Bekerja di Luar Rumah Tangga

\begin{tabular}{cllc}
\hline No & \multicolumn{1}{c}{ Alasan-alasan } & Jumlah (jiwa) & $\begin{array}{c}\text { Persentase } \\
(\%)\end{array}$ \\
\hline 1. & $\begin{array}{l}\text { Alasan ekonomi yaitu karena merasa cukup } \\
\text { dengan kondisi ekonomi sekarang }\end{array}$ & 10 & 31,25 \\
2. & Alasan sosial yaitu pendidikan yang rendah. & 17 & 53,13 \\
3. & Alasan budaya yaitu tidak diizinkan suami & 5 & 15,62 \\
\hline & Jumlah & 32 & 100 \\
\hline Sumber : Data Primer, 2005
\end{tabular}

Faktor-faktor Yang Mempengaruhi Istri petani Memilih Bekerja atau Tidak Bekerja di Luar Rumah Tangga.

Jumlah perempuan yang memilih pilihan 1 adalah sebesar 36 orang $(52,94 \%)$ dan perempuan yang memilih pilihan 0 adalah sebanyak 32 orang $(47,06 \%)$. Hal ini menunjukkan bahwa perempuan lebih banyak memilih bekerja dari pada tidak bekerja di luar rumah tangga. Untuk mengetahui faktor pendidikan formal, pendidikan non formal, umur, jumlah pendapatan suami dan jumlah tanggungan keluarga terhadap pemilihan bekerja atau tidak bekerja di luar rumah tangga digunakan model regresi logit. Berdasarkan estimasi regresi faktor-faktor yang mempengaruhi pemilihan istri petani untuk bekerja atau tidak bekerja di luar rumah tangga diperoleh persamaan sebagai berikut

$$
\begin{aligned}
& Y=0,500 X_{1}{ }^{*}+0,2917 X_{2}{ }^{*}-0,0066 X_{3}{ }^{*}-2,295 \times 10^{-7} X_{4}+0,1272 X_{5}{ }^{*} \\
& \text { Se }=(0,0185) \quad(0,0857) \quad(0,0058) \quad(6,99953 \times 10-8) \quad(0,0463) \\
& T \text {-hit }=(2,71) \quad(3,403) \quad(-1,132) \quad(-3,279) \quad(2,746)
\end{aligned}
$$

Keterangan: * = Berpengaruh Nyata pada taraf kepercayaan $95 \%$

Dari hasil analisis dapat diketahui bahwa secara bersama-sama variabel yaitu pendidikan formal, pendidikan non formal, umur, jumlah pendapatan suami dan jumlah tanggungan keluarga mempengaruhi istri petani memilih bekerja atau tidak bekerja di luar rumah tangga, dengan nilai $F$ hitung sebesar 8,961 lebih besar dari $F$ tabel $(2,363)$ pada tingkat kepercayaan 95\%. Hal ini berarti bahwa pemilihan bekerja atau tidak bekerja secara nyata dipengaruhi oleh perubahan nilai variabel-variabel diatas.Secara bersama-sama variabel diatas mampu menjelaskan perubahan pemilihan istri petani bekerja atau tidak bekerja di luar rumah tangga sebesar $41,90 \%$ yang ditunjukkan oleh nilai-nilai $\mathrm{R}^{2}$ persamaan regresi sebesar 0,4190 , sedangkan sisanya $58,10 \%$ dipengaruhi oleh faktor lain yang tidak dimasukkan dalam model. 
Tingkat pendidikan formal berpengaruh nyata terhadap pemilihan tidak bekerja atau bekerja di luar rumah tangga oleh istri petani. Dimana nilai t hitung sebesar 2,701 lebih besar daripada t tabel sebesar 2,297, maka Ho ditolak dan Ha diterima. Hal ini berarti semakin tinggi pendidikan formal maka istri petani memilih bekerja di luar rumah tangga. Hasil penelitian ini didukung oleh hasil penelitian Suteky (2000) dalam Priyono (2004) tentang curahan kerja perempuan dalam usaha sapi potong yang menyatakan bahwa semakin tinggi pendidikan formal maka akan semakin besar pula curahan kerja perempuan untuk mencari nafkah. Dapat dijelaskan pula bahwa semakin tinggi pendidikan formal maka perempuan memilih bekerja di luar rumah tangga, karena pendidikan merupakan salah satu perubah status, kemampuan dan keahlian seseorang. Hal ini akan memungkinkan aspirasi dan harapan akan penghasilan yang lebih baik dan akan mendorong mereka untuk bekerja lebih giat (Boserup 1995 dalam Rospida, 1997).

Pendidikan non formal berpengaruh nyata terhadap pemilihan bekerja di luar rumah tangga oleh istri petani. Hasil penelitian menunjukkan bahwa nilai t hitung $(3,403)>$ nilai t tabel $(2,297)$ pada tingkat kepercayaan 95\% maka Ho ditolak dan Ha diterima. Hal ini berarti bahwa semakin tinggi frekuensi pendidikan non formal yang diikuti istri petani, maka istri petani memilih bekerja di luar rumah tangga. Pendidikan non formal memberikan istri petani kemampuan dan keterampilan. IImu yang diperoleh dari mengikuti pendidikan non formal dapat mereka gunakan untuk mendapatkan penghasilan. Semakin sering mengikuti pendidikan non formal akan menambah pengetahuan perempuan dalam barbagai hal, seperti pelatihan pembuatan makanan ringan, pada mulanya perempuan membuat untuk keluarga mereka sehingga dapat mengurangi pengeluaran. Setelah itu mereka membuat dalam jumlah yang lebih besar sehingga dapat mereka jual untuk menperoleh pendapatan.

Hasil penelitian menunjukkan bahwa faktor umur tidak berpengaruh nyata terhadap keputusan perempuan untuk memilih bekerja di luar rumah tangga. Hal ini dapat dilihat dari hasil uji t dimana diperoleh nilai -t hitung $(-1,132)>$-t tabel $(-2,297)$ pada tingkat kepercayaan $95 \%$, maka Ho diterima dan Ha ditolak. Tidak berpengaruh nyatanya umur terhadap pemilihan bekerja di luar rumah tangga dikarenakan bekerja di luar rumah tangga dapat dilakukan oleh siapa saja tanpa membatasi umur dan tidak semua perempuan yang berusia produktif memilih untuk bekerja di luar rumah tangga, karena pada penelitian ini istri petani yang berusia produktif memilih tidak bekerja atau tetap tinggal di rumah untuk mengurus keluarganya, sehingga tidak terpengaruh pada kondisi umur dalam melakukan kegiatan. 
Hasil penelitian menunjukkan bahwa jumlah pendapatan suami berpengaruh nyata terhadap pemilihan tidak bekerja atau bekerja di luar rumah tangga oleh istri petani. Hal ini dapat dilihat dari nilai -t hitung $(-3,279)<-t$ tabel $(-2,297)$ pada tingkat kepercayaan 95\% maka Ha diterima dan Ho ditolak. Semakin tinggi pendapatan suami maka istri petani cenderung memilih untuk tidak bekerja di luar rumah tangga dan sebaliknya, rendahnya pendapatan suami akan mendorong istri untuk mencari nafkah demi memenuhi kebutuhan keluarga.Berpengaruh nyatanya pendapatan suami dengan pemilihan perempuan bekerja di luar rumah tangga dapat dimengerti karena dengan semakin rendahnya pendapatan suami akan semakin sulit dalam mencukupi kebutuhan keluarga. Hal ini akan mendorong perempuan untuk memilih bekerja diluar rumah tangga untuk memperoleh pendapatan.

Koefisien regresi jumlah tanggungan keluarga yaitu 0,127. Hasil t hitung $(2,746)>t$ tabel $(2,279)$ pada tingkat kepercayaan $95 \%$ berarti Ho ditolak dan Ha diterima. Berarti semakin tinggi jumlah tanggungan keluarga, perempuan akan memilih bekerja di luar rumah tangga. Hal ini dapat dimengerti karena dengan semakin banyaknya jumlah tanggungan keluarga maka akan mempengaruhi jumlah kebutuhan rumah tangga baik kebutuhan primer maupun kebutuhan sekunder. Dengan semakin meningkatnya kebutuhan maka akan mendorong perempuan untuk memperoleh pendapatan, sehingga secara langsung akan mempengaruhi perempuan memilih bekerja di luar rumah tangga demi memenuhi kebutuhan keluarga.

\section{Kontribusi Pedapatan.}

Salah satu kenyataan sumbangan perempuan dalam pembangunan adalah partisipasi perempuan sebagai pekerja dalam berbagai bidang kehidupan. Konsekuensi dari partisipasi tersebut tampak dari berbagai masalah yang dihadapi, lebih-lebih jika mengingat peran ganda dalam rumah tangga dan masyarakat luas. Untuk itu hasil penelitian ini akan dipaparkan besar kontribusi pendapatan perempuan yang bekerja terhadap pendapatan rumah tangga. Secara rinci Tabel. 5 akan menjelaskan mengenai sumber, jumlah pendapatan rumah tangga dan kontribusi pendapatan perempuan yang bekerja terhadap pendapatan rumah tangga. 
Tabel. 5. Sumber Pendapatan, Jumlah dan Besarnya Kontribusi Pendapatan terhadap Pendapatan Rumah Tangga.

\begin{tabular}{lcc}
\hline \multicolumn{1}{c}{ Sumber Pendapatan } & Rata-rata pendapatan & Kontribusi (\%) \\
\hline - Pendapatan suami & $573.305,56$ & 43,06 \\
- Pendapatan Istri & $1.344 .027,78$ & 56,94 \\
\hline Total & $1.917 .333,34$ & 100,00 \\
\hline
\end{tabular}

Sumber : Data primer, 2005

Dari tabel diatas memperlihatkan bahwa sumber pendapatan rata-rata suami per bulan Rp 573.305,56 dengan persentase 43,06\%. Sedangkan sumber pendapatan istri rata-rata per bulan yaitu 1.344.027,78 dengan persentase sebesar 56,94\%. Pendapatan yang diperoleh adalah pendapatan kotor dari keluarga.Sumbangan pendapatan responden diklasifikasikan kontribusinya terhadap pendapatan keluarga dengan klasifikasi sangat rendah, rendah, sedang/cukup, tinggi dan sangat tinggi. Kontribusi pendapatan rata-rata istri petani yang memilih bekerja sebesar $56,94 \%$. Hal ini menunjukkan bahwa kontribusi dari kegiatan ini termasuk dalam kategori atau klasifikasi sedang/cukup

\section{KESIMPULAN DAN SARAN}

\section{Kesimpulan}

Bedasarkan hasil penelitian maka dapat disimpulkan bahwa:

1. Alasan-alasan yang menyebabkan istri petani memilih bekerja di luar rumah tangga meliputi 3 aspek yaitu alasan ekonomi, alasan sosial dan budaya. Alasan-alasan istri petani memilih untuk tidak bekerja di luar rumah tangga meliputi 3 aspek yang pertama adalah alasan ekonomi, alasan sosial, dan alasan budaya.

2. Faktor-faktor yang mempengaruhi istri petani memilih untuk tidak bekerja atau bekerja di luar rumah tangga adalah pendidikan formal, pendidikan non formal, jumlah pendapatan suami, jumlah tanggungan keluarga. Sedangkan faktor umur tidak berpengaruh nyata terhadap pemilihan perempuan untuk bekerja atau tidak bekerja di luar rumah tangga.

1. Besarnya kontribusi pendapatan yang diberikan istri petani yang bekerja terhadap pendapatan rumah tangga adalah sebesar 56,94\% dan termasuk dalam kategori sedang/cukup.

\section{Saran}

1. Bagi perempuan yang memilih bekerja, dalam upaya meningkatkan kualitas tenaga kerja perempuan perlu ditingkatkannya pendidikan perempuan baik pendidikan formal maupun non 
formal sehingga perempuan dapat memanfaatkan kesempatan kerja yang ada, tidak hanya di wirausaha tetapi mampu menjadi tenaga kerja berkualitas di berbagai bidang, sehingga dapat meningkatkan pendapatan atau menambah pendapatan rumah tangga.

2. Mengingat kontribusi yang diberikan oleh ibu rumah tangga yang bekerja di luar rumah tangga sangat membantu ekonomi rumah tangga, hendaknya istri petani yang tidak bekerja dapat menambah ilmu pengetahuan, mengikuti pendidikan maupun pelatihan-pelatihan yang diadakan di lingkungan desa sebagai suatu informasi yang dapat digunakan bila suatu saat diperlukan.

\section{DAFTAR PUSTAKA}

Aprizal. 2002. Analisis Perilaku Konsumen Buah Jeruk Pada Rumah Tangga dan Faktor-faktor Yang Mempengaruhinya (Studi Kasus di Kota Bengkulu). Skripsi Jurusan Sosial Ekonomi Pertanian. Fakultas Pertanian.Universitas Bengkulu. (Tidak dipublikasikan)

Ambarini, Deva Y. 2002. Kajian Wanita Pemetik Teh dan Faktor-faktor yang Mempengaruhi Pendapatannya (Studi Kasus di Desa Air Sampiang Kec. Kepahiang Kab. Rejang Lebong). Skripsi. Sosial Ekonomi Pertanian. Fakultas Pertanian. Universitas Bengkulu. (Tidak dipublikasikan)

Atika, E. 1997. Hubungan Tingkat Pendidikan Formal dengan Pola Pengambilan Keputusan dalam Keluarga (Studi Kasus pada Warga Kelurahan Kebun Kenanga Kecamatan Gading Cempaka Kotamadya Bengkulu). Skripsi. Fakultas IImu Sosial dan IImu Politik. Universitas Bengkulu. (Tidak dipublikasikan)

Budianto.M, Bambang. 2003. Analisis Pendapatan dan ResikoUsaha Agrolndustri Pengolahan Ikan Kering Yang Dikelola oleh Wanita. Skripsi jurusan Sosek. Fakultas Pertanian. Universitas Bengkulu (Tidak dipublikasikan)

Diana, Vera. 1998. Sumbangan Industri Rumah Tangga Wanita Transmigran terhadap Pendapatan Rumah Tangga. Skripsi Jurusan Sosial Ekonomi.Fakultas Pertanian.Universitas Bengkulu. (Tidak dipublikasikan)

Fahrulliah, Arsilawati. 2004. Analisis Pendapatan Wanita Pedagang Sayur Bersepeda dan Pola Pengambilan Keputusan di Kota Bengkulu. Skripsi Jurusan Sosial Ekonnomi Pertanian. Fakultas Pertanian. Universitas Bengkulu.(Tidak dipublikasikan)

Handoko, H. 1990. Manajemen Sumber Daya Manusia. BPFE. Yogyakarta.

Hendra, Dodi. 1998. Tingkat Partisipasi Kerja dan Upah dalam aspek Gender di Indonesia Tahun 1994. Skripsi Jurusan Studi Pembangunan. Fakultas Ekonomi. Universitas Bengkulu. (Tidak dipublikasikan)

Mersandi. 2001. Analsis Faktor-Faktor Yang Mempengaruhi Pendapatan Rumah Tangga Transmigran (Studi Kasus di Desa Air Sulau Bengkulu Selatan). Skripsi Jurusan Sosial Ekonnomi Pertanian. Fakultas Pertanian. Universitas Bengkulu.(Tidak dipublikasikan) 
Nazir, Moh, Ph.D. 1998. Metode Penelitian.Ghalia Indonesia.Jakarta.

Nurzaleha. 1996. Analisis Kehidupan Wanita Pemetik Daun Teh di PT. Sarana Mandiri Mukti Kabawetan Kecamatan Kepahiang Kabupaten Rejang Lebong. Skripsi. Fakultas IImu Sosial dan IImu Politik. Universitas Bengkulu. (Tidak dipublikasikan).

Pratiwi, RN dan R.Adiono. 2003. Hubungan Publik Figur Wanita Nikah dengan Intensitas Konflik di Daerah Perkotaan. Jurnal Ilmu-ilmu Sosial, 15 (2).

Priyono, Basuki S, M. Nurung. Yesi Kurniawati. 2004.Peranan Perempuan Pedagang Pengecer Ikan di Kota Bengkulu Terhadap Pendapatan Rumah Tangga dan Proses Pengamblan Keputusan Keluarga. Jurnal Agrisep 3 (1) : 56-66. Jurusan Sosial Ekonomi Pertanian FP UNIB. Bengkulu.

Pudjiwati, S.1985. Peranan Wanita dalam Perkembangan Masyarakat Desa.Penerbit CV Rajawali. Jakarta.

Purnamawati, S. 1996. Faktor-faktor yang Mempengaruhi Curahan Jam Kerja Wanita (Studi Kasus pada Desa Tertinggal) di Kotamadya Bengkulu. Skripsi. Fakultas Ekonomi.Universitas Bengkulu. (Tidak dipublikasikan)

Rahardjo, Julfita. 1986. Wanita Kota Jakarta (Kehidupan Keluarga dan Keluarga Berencana). Gadjah Mada University Press. Jakarta

Sajogyo, Pudjiwati. 1996. Sosiologi Pedesaan. Gadjah Mada University Press. Yogyakarta

Singarimbun Masri dan Sopyan Efendi.1989. Metode Penelitian Survey. Lp3S. Jakarta.

Suhendri dan Ramdhani, W. 2000. Pengantar Studi Sosiologi Keluarga. Pustaka Setia. Bandung.

Sularno. 2003. Selayang Pandang Desa Pekik Nyaring.Bengkulu.

Sumantri, B dan Budi Ansori. 2004. Kontribusi Pendapatan Ibu Rumah Tangga Terhadap Pendapatan Keluarga. Agrisep, 2 (2) ; 103

Supranto, J. 1983. Ekonometrika. Edisi Satu. LPFE, UI, Jakarta.

Syuaib, D. 2003. Wanita Kaili Tenun Kain Sutra dan Permasalahannya. Jurnal IImu-ilmu Sosial, Vol. 15 No. 1

Wijaya.1995. Mewujudkan Kemitraan Sejajaran Pria - Wanita Dalam Pembangunan Indonesia. Penerbit IKIP Malang.

Yuliani.1991. Analisis Kontribusi Kerja Anggota Keluarga Terhadap Pendapatan Keluarga di Kecamatan Gading Cempaka Kotamadya Bengkulu. Skripsi. Fakultas ekonomi. Universitas Bengkulu. (Tidak dipublikasikan)

Zulkarnain, M. 1998. Analisis Faktor-faktor yang Mempengaruhi Produktivitas Tenaga Kerja Wanita Pemetik Teh pada PT. Sarana Mandiri Mukti Kabawetan Kecamatan Kepahiang Kabupaten Rejang Lebong. Skripsi. Fakultas Pertanian. Universitas Bengkulu. (Tidak dipublikasikan) 